\title{
Network Effects in Countries' Adoption of IFRS
}

\section{Citation}

Ramanna, Karthik, and Ewa Sletten. "Network Effects in Countries' Adoption of IFRS."

Accounting Review (forthcoming).

\section{Published Version}

http://dx.doi.org/10.2308/accr-50717

\section{Permanent link}

http://nrs.harvard.edu/urn-3:HUL.InstRepos:12175233

\section{Terms of Use}

This article was downloaded from Harvard University's DASH repository, and is made available under the terms and conditions applicable to Open Access Policy Articles, as set forth at http:// nrs.harvard.edu/urn-3:HUL.InstRepos:dash.current.terms-of-use\#OAP

\section{Share Your Story}

The Harvard community has made this article openly available.

Please share how this access benefits you. Submit a story.

Accessibility 
H A R VAR D

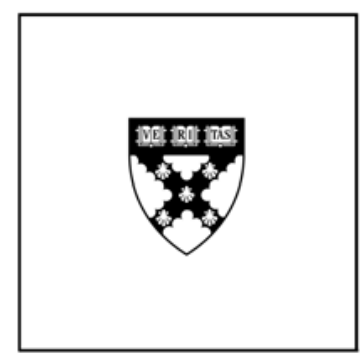

\title{
Network Effects in Countries' Adoption of IFRS
}

\author{
Karthik Ramanna \\ Ewa Sletten
}

\section{Working Paper}

10-092

August 22, 2013 


\title{
Network Effects in Countries' Adoption of IFRS*
}

\author{
Karthik Ramanna \\ Harvard Business School \\ kramanna@hbs.edu \\ and \\ Ewa Sletten \\ Boston College \\ ewa.sletten@bc.edu
}

This draft: July 26, 2013

\begin{abstract}
If the differences in accounting standards across countries reflect relatively stable institutional differences (e.g., auditing technology, the rule of law, etc.), why did several countries rapidly, albeit in a staggered manner, adopt IFRS over local standards in the 2003-2008 period? We test the hypothesis that perceived network benefits from the extant worldwide adoption of IFRS can explain part of countries' shift away from local accounting standards. That is, as more jurisdictions with economic ties to a given country adopt IFRS, perceived benefits from lowering transactions costs to foreign financial-statement users increase and contribute significantly towards the country's decision to adopt IFRS. We find that perceived network benefits increase the degree of IFRS harmonization among countries, and that smaller countries have a differentially higher response to these benefits. Further, economic ties with the European Union are a particularly important source of network effects. The results, robust to numerous alternative hypotheses and specifications, suggest IFRS adoption was self-reinforcing during the sample period, which, in turn, has implications for the consequences of IFRS adoption.
\end{abstract}

\footnotetext{
* We thank John Core, David Hawkins, Michelle Hanlon, Paul Healy, Bob Holthausen, Bin Ke (the editor), S.P. Kothari, Christian Leuz, Shiva Rajgopal, Sugata Roychowdhury, Eddie Riedl, Terry Shevlin, D. Shores, Doug Skinner, Thor Sletten, Eugene Soltes, Suraj Srinivasan, Rodrigo Verdi, Ross Watts, Joe Weber, Gwen Yu, Steve Zeff, the anonymous reviewers, and seminar participants at Arizona State, Boston College, Boston University, Emory, the Harvard Applied Statistics Workshop, HBS, MIT, Rice University, UCLA, U. of Colorado-Boulder, U. of Minnesota, U. of Oregon, U. of Toronto, U. of Washington, the 2009 GIA Conference at UNC-Chapel Hill, the 2010 European Accounting Association Annual Meeting, and the 2010 Penn State Accounting Conference for helpful suggestions and comments. The paper is based in part on our earlier manuscript, "Why do countries adopt IFRS?” Any errors are our responsibility.
} 


\section{Introduction}

The International Accounting Standards Board (IASB) was established in 2001 to develop International Financial Reporting Standards (IFRS). In the period from 2003 through 2008, more than 50 countries (including the EU countries) mandated IFRS for all listed companies in their jurisdictions. Further, in that period, another 15 countries either mandated IFRS for some listed companies or allowed listed companies to voluntarily adopt IFRS. Another group of 15 countries initiated "convergence" projects with IFRS through 2008, and the list of states with convergence projects extending beyond 2008 includes some of the world's largest economies such as China and the U.S., ${ }^{1,2}$ There has been considerable research into the consequences of a country's IFRS adoption for firms in its jurisdiction (e.g., Armstrong, Barth, Jagolinzer, and Riedl, 2010; Daske, Hail, Leuz, and Verdi, 2008; DeFond, Hu, Hung, and Li, 2011; and Lang, Maffett, and Owens, 2010); but less is known about why countries themselves adopt IFRS. The notable exception is Hope, Jin, and Kang (2006) who find that disclosure practices, investor protection, accessibility of equity markets to firms, and the size of equity markets are linked to countries' adoption decisions. We complement this research by developing and testing the hypothesis that the intertemporal shift towards IFRS over local standards can also be explained by perceived network benefits, i.e., perceived lower transactions costs, given the network of IFRS adopters. If true, the implication is that worldwide IFRS acceptance is selfreinforcing, i.e., adoption begets adoption.

\footnotetext{
${ }^{1}$ Throughout the paper, "convergence" refers to a country's efforts to reconcile its domestic accounting standards with IFRS, in lieu of directly adopting IFRS as issued by the IASB. Convergence projects often result in adopting IFRS with modifications and exceptions.

${ }^{2}$ On July 13, 2012, the Office of the Chief Accountant of the U.S. Securities \& Exchanges Commission issued a staff report that effectively delayed the possibility of U.S. adoption of IFRS indefinitely. See http://www.sec.gov/news/press/2012/2012-135.htm.
} 
Prior literature argues that financial reporting standards have co-developed with a country's economic, political, and cultural institutions (e.g., Ball, Kothari, and Robin, 2000; Ball, Robin, and Wu, 2003; Bushman and Piotroski, 2006; Bradshaw and Miller, 2008; and Hail, Leuz, and Wysocki, 2010). In particular, the nature of standards comprising a reporting regime reflects the monitoring and information processing capabilities of existing market institutions such as auditing, securities laws, courts, and financial intermediaries. Under this view, a change in a country's financial reporting standards should accompany complementary changes in monitoring and information processing institutions. However, the rapid proliferation in IFRS adoption across countries in the 2003-2008 period has seldom been accompanied by substantial changes in enforcement institutions ${ }^{3}$, suggesting that other forces are likely driving this process.

The staggered adoption of IFRS over time can be due, in part, to changing perceptions across countries of the benefits of IFRS. IFRS, as a globally recognized body of standards, is expected to lower transaction costs associated with foreign users of financial statements. By adopting IFRS, a country trades off status quo national standards that reflect its market institutions for (in part) a perceived decrease in transactions costs from using internationally recognized standards. As more jurisdictions with economic ties to a given country adopt IFRS, the perceived benefits to that country from lowering transactions costs, and thus from adopting IFRS, increase. Thus, we hypothesize that a country's adoption of IFRS is related to the magnitude of its economic relations with other countries that have adopted IFRS through that date. We refer to this magnitude as the IFRS network value to a country at a given time.

The first step in an empirical test of IFRS network effects is identifying IFRS adoption among countries. The nature of IFRS adoption by a country (e.g., converging local standards

\footnotetext{
${ }^{3}$ See for example, the discussions in Ball, 2006; and Leuz, 2010. Further, the World Bank cites inadequate enforcement as a key challenge for nearly every emerging market that is harmonizing with IFRS (as catalogued in its country-level Reports on Observance of Standards and Codes).
} 
with IFRS, permitting firms to voluntarily adopt IFRS, full IFRS adoption, etc.) varies across jurisdictions and time. Thus, our primary IFRS adoption variable is an ordinal reflecting the variety of possible adoption states. The variable takes three values: "1" for country-years with no IFRS-related activities; "2" for country-years with convergence projects, country-years in which voluntary IFRS adoption is permitted, and country-years in which IFRS is required for some listed firms; and "3" for country-years with full IFRS adoption for listed firms. The variable is constructed for each country-year in a sample of 92 jurisdictions for the period 2003-2008. ${ }^{4}$

The second step in our empirical tests involves measuring the perceived network benefits to a country from adopting IFRS in a given year. Countries expect economic network benefits from IFRS adoption because common accounting standards are likely to lower the cost of foreign investment and trade. Capital-market effects of accounting have been studied extensively and it is thus naturally intuitive that network benefits can arise from the anticipated effect of common standards on foreign direct investment or foreign equity portfolio investment. Another area in which accounting standards can also play an important role is foreign trade. Cross-border customer and supplier contracts are usually written on accounting numbers since this helps the contracting parties manage supply-chain risk and monitor counterparties when the terms of trade include financing. Consequently, harmonization of accounting standards can also lower transaction costs of trade, including costs of information and monitoring. A measure of perceived network benefits would thus ideally be based both on international investment flows and trade. However, because of investment flow data limitations ${ }^{5}$, we construct various network benefit

\footnotetext{
${ }^{4}$ Throughout the paper, we use the term "country" interchangeably with "jurisdiction;" but our sample properly refers to "jurisdictions." This is because the EU and the EEA member-states are represented as a single observation among the 92 jurisdictions (since these countries adopted IFRS jointly) and because Hong Kong is treated separately from China (since it has a different legal, political, and market institutions that govern accounting).

${ }^{5}$ As explained in more detail in Section III, measures of network effects require bilateral foreign investment flows (in order to capture a country's economic relations only with the subset of jurisdictions that have adopted IFRS). These data are available only for a small subsample of (mostly larger) countries.
} 
measures that are based only on the country's trade with IFRS-incorporating jurisdictions. Therefore, we caveat our tests as capturing only a subset of potential network effects perceived by countries.

Our primary empirical tests involve regressing, in a country-year panel, the IFRS adoption status on perceived network benefits. Because network effects are measured at the country-year level, we can include country and year fixed effects in the regression. The country fixed effects allow us to control for cross-sectional variation in country-specific institutional features that influence the choice of accounting standards (e.g., enforcement institutions). The year fixed effects control for time-based explanations that might lead to a spurious correlation between IFRS harmonization and our network-effects variable. These fixed effects do not, however, control for alternative explanations that are panel-based, and consequently, we also include in our regressions a number of control variables that vary both cross-sectionally and in time. We focus on explanations captured by variables associated with our measure of network effects (and thus, potentially confounding the interpretation of our empirical tests). Among these explanations, we test whether IFRS harmonization is simply a part of a country's broader policy response to globalization, beyond increasing economic relations with IFRS adopters, and whether it is driven by changes in a country's government. We also examine the World Bank's role in the worldwide IFRS proliferation (World Bank, 1998-2008), and whether a country's decision to adopt IFRS is related to the entry of the Big 4 auditors into that jurisdiction. Finally, we control for changes in domestic institutions and enforcement.

Consistent with our main hypothesis, we find that a country's IFRS adoption status, as measured by our ordinal dependent variable, is an increasing function of the perceived value of its IFRS network, even after controlling for country and time fixed effects and the alternative 
explanations described above. We further expect a country's economic size to temper the perceived effects of a growing IFRS network on the choice of accounting standards. Larger countries, due to the size of their markets, are likely to attract foreign capital and maintain international trade even if they continue using domestic standards. Thus, we expect larger (higher GDP) countries to be less swayed towards IFRS adoption by the value of their IFRS networks.

Our evidence is consistent with network effects mattering less to countries with larger GDPs. For countries in the largest size quartile, an inter-quartile increase in perceived network benefits is associated with $5 \%$ of the shift from no IFRS-related activities (level " 1 ") to some harmonization efforts (level “2”); by contrast, for countries in the smallest size quartile, an interquartile increase in perceived network benefits is associated with $46 \%$ of the shift from level " 1 " to level "2." These findings suggest that a country's relative economic power shapes its response to the increasing worldwide adoption of IFRS: economically powerful countries are more likely to refrain from adopting IFRS or tailor their harmonization with IFRS extensively. ${ }^{6}$

In defining network effects, we focus on economic relations because they are likely to have a first order effect on financial reporting. Network effects may also arise from geographic proximity and relations with erstwhile colonizers. ${ }^{7}$ For example, as countries located in a certain geographic region adopt IFRS, remaining countries in that region may also choose to adopt IFRS. Similarly, as a country's former colonizer adopts IFRS, shared linguistic, cultural, and institutional ties might drive it to adopt IFRS. Both geographic and colonizer effects can exist

\footnotetext{
${ }^{6}$ Anecdotal evidence from China's process of converging with IFRS is consistent with this finding: Ramanna, Donovan, and Dai (2010) describe various exceptions to IFRS China has carved out as a condition to converging with the global standards.

${ }^{7}$ The notions of geographic, cultural and industrial proximity have been hypothesized and shown to affect firms' cross-listing behavior (Sarkissian and Schill, 2004).
} 
independently of economic networks; thus, we test the robustness of our results to both these effects. Our key results are unchanged in these robustness tests.

Overall, the evidence in this paper suggests that perceived network benefits are an important determinant of IFRS adoption over time. Smaller countries are particularly sensitive to network effects, adopting IFRS because others are doing so even though their institutions may not be particularly well suited to this set of standards. In additional tests, we find evidence consistent with IFRS adoption by the EU and EEA member states being a particularly significant source of perceived network benefits for other jurisdictions.

Our findings complement those in Hope, Jin and Kang (2006) who focus on a crosssectional analysis of country-level determinants of IFRS adoption. The substantial time-series data on IFRS adoptions that has since become available allows us to test the dynamic hypothesis that the worldwide proliferation of IFRS is due in part to network effects. Our evidence has significant implications for the world-wide prospects of IFRS - as more countries adopt IFRS, it becomes more costly for (smaller) countries to remain outside of the IFRS network.

Since we conceptualize and measure network benefits ex ante, i.e., as a determinant (not consequence) of IFRS adoption, our evidence does not speak to whether these network benefits are realized. By the same token, evidence on the effect of IFRS adoption on trade and foreign investment (Marquez-Ramos, 2008) is insufficient to conclude that countries perceived lower cost of trade as an important factor in their decision to adopt IFRS. Consequences of IFRS adoption are not uniform across firms located in different countries and are sometimes undesirable (Daske, Hail, Leuz and Verdi, 2008; Defond, Hu, Hung and Li, 2011), which implies that perceived benefits may not always be realized and that some consequences of IFRS adoption are likely unintended. Hence, even when ex post trade consequences have been previously 
examined, our study of ex ante determinants is important for at least three reasons. First, our evidence adds context to findings from existing firm-level studies on IFRS adoption. While governments likely consider the expected firm-level consequences in their decisions to adopt IFRS, firms adopt the standards only after their government allows them or requires them to do so. Second, the evidence on network effects suggests a country can adopt IFRS even if its domestically developed accounting standards are particularly well-suited to its domestic institutions. Finally, a literature in economics has shown that when network effects contribute to the dominance of a standard, even superior innovations in the future may not be implemented (e.g., the QWERTY keyboard; David, 1985; Katz and Shapiro, 1985). While our evidence cannot establish this will be the case with IFRS, the evidence is germane in the context of prior research on network effects.

The remainder of this paper is organized as follows. Section II develops our hypotheses. Section III describes the cross-country dataset on IFRS adoption and our measures of IFRS network values. That section also describes the research design, including our tests of alternative explanations. Section IV describes the results. Section V describes robustness tests and additional analyses. Section VI concludes.

\section{Hypotheses development}

Prior literature argues that a country's financial reporting standards co-develop with the economics, politics, and culture of its institutions like auditing, securities laws, courts, and financial intermediaries. One implication from this literature is that institutional differences across societies can explain countries' choices on IFRS (i.e., adopt or not). In this vein, Hope et al. (2006) provide evidence that disclosure practices, investor protection, accessibility of equity markets to firms, and the size of equity markets are linked to country's adoption decisions. 
Notwithstanding institutional differences, IFRS has grown in popularity over six years, as seen by the increasing number of countries attempting to harmonize with IFRS between 2003 and 2008 , and it remains to be explained why so many countries adopted IFRS so quickly. We hypothesize that network benefits from extant worldwide adoption of IFRS are significant determinants in the time-series decision on IFRS harmonization by any given country. ${ }^{8}$

To understand the role of network benefits in IFRS adoption, it is helpful to consider in parallel the example of a popular network-dependent product, Facebook. ${ }^{9}$ The value to a user from adopting Facebook as a communication portal is driven by three distinct sources: (1) the demand for a communication portal; (2) the features on Facebook (e.g., applications and customizability); and (3) the number of other Facebook users. The first two sources are direct benefits from adopting Facebook, while the third source is the value from Facebook's network. The role of network benefits in adopting Facebook can be explained by perceived lower transactions costs, given the extant group of Facebook adopters. A similar argument can be made with respect to IFRS and we elaborate on this point below.

IFRS, as a globally recognized body of standards, is expected to lower transactions costs for foreign users of financial statements. That is, foreign financial statement users already familiar with IFRS through their own adoption of the standards are expected to incur lower barriers in analyzing overseas financials prepared under IFRS, which in turn can result in benefits accruing to entities reporting under these standards. As more jurisdictions with economic ties to a given country adopt IFRS, the perceived benefits to that country from lowering transactions costs to foreign users, and thus from adopting IFRS, can increase. Consequently, we hypothesize that a country's adoption of IFRS (holding constant institutional

\footnotetext{
${ }^{8}$ Währisch (2001) describes how network effects can motivate firms to adopt international accounting systems.

${ }^{9}$ A well-developed theoretical literature in economics explores the notion of network effects. See for example, Katz and Shapiro (1985), Liebowitz and Margolis (1994; 1998).
} 
determinants) can be explained, in part, by the magnitude of its economic relations with other countries that have adopted IFRS through that date. We refer to this magnitude as the value of the IFRS network to a country at a given time.

The nature of a country's economy is likely to temper or intensify the perceived value of IFRS network to the country. We exploit this argument and examine how a country's economic size affects its sensitivity to perceived network benefits. We expect larger countries (i.e., countries with higher GDP) to be less swayed towards IFRS adoption by the value of their IFRS networks. Larger countries are likely to have greater bargaining power with their economic partners due to the size of their markets, and, as a result, are likely to attract foreign capital and maintain international trade even if they continue using domestic standards. In contrast, smaller countries, with less bargaining power and smaller domestic markets, are more likely to see IFRS adoption as a means to grow and/or lower the cost of existing foreign trade and investment, particularly as the size of their IFRS adoption network grows. For example, speaking of Ghana's decision to adopt IFRS, the head of its chartered accountancy body noted in 2006 that the country "had no choice but to wake up and join the bandwagon" (Modern Ghana, 2006). Similarly, speaking in August 2007 of his country's decision to adopt IFRS, Fiji's lead standardsetter noted that the decision was consistent with "responding positively to shifts in public expectations and new market opportunities" (Patel, 2007). Also, as Armenia's finance minister received translated IFRS standards in 2010 from the local USAID office (which paid for the translation), the minister noted that IFRS provided "Armenian business enterprises ... increased access to international capital markets" while the local USAID chief noted that IFRS in Armenia was "essential for trade facilitation" (USAID Armenia, 2010). Finally, as Nepal decided to adopt IFRS in 2012, its standards board noted that the decision would help the country "make its 
presence felt in the global market" and "help domestic companies attract strategic partners" (Himalayan News Service, 2012).

Consequently, we predict that smaller countries (lower GDP) are more sensitive to the perceived network benefits of IFRS adoption.

\section{Metrics and research design}

\section{Measuring IFRS adoption}

Below, we describe the construction of our database of IFRS adoption by country-year. While our research question concerns the role of network effects in countries' adoption decisions, we are unable to obtain complete information on the decision dates of IFRS adoption for a broad sample of countries. Consequently, we use actual adoption dates as a gauge for adoption decision dates. We compile information on the status of a country's IFRS adoption in every year between 2003 and 2008. We begin our database in 2003 because we are interested in IFRS as developed and sponsored by the IASB and 2002 was the first full year of the IASB's existence; we end our sample in 2008 because data to construct variables in our study were not available beyond 2008 at the time we initiated this project. For the handful of jurisdictions for which we are able to identify IFRS adoption decision dates, we calculate the distance between adoption decision and implementation dates. The mean and median distance is two years. Thus, our data on IFRS adoptions between 2003 and 2008 corresponds, on average, to adoption decisions made between 2001 and 2006.

We use three primary sources of data on IFRS adoption: (1) Deloitte \& Touche's IASplus.com website; (2) a similar internet database from PriceWaterhouseCoopers; and (3) data from the World Bank's country Reports on Observance of Standards and Codes (ROSC reports). Deloitte's website lists IFRS adoption information for 153 legal jurisdictions (including 30 
jurisdictions in the EU/ European Economic Area, EEA), although the information for several countries is not up-to-date. PriceWaterhouseCoopers' website provides similar adoption information as of the end of 2008 for 109 countries (including 26 jurisdictions in the EU/ EEA). The ROSC reports are comprehensive reviews of individual countries' accounting and auditing regulations, and also include discussions of other related issues such as accounting education and enforcement. The ROSC reports are available for 74 developing countries (the reports are usually prepared for World Bank client countries), but some of the reports date as far back as 2001 and cannot be fully relied on for more current information.

In coding a country's IFRS adoption we use information from all three data sources, when available. Each data source covers a slightly different set of countries, and their assessments of the extent of IFRS adoption occasionally differ for those countries they cover in common. ${ }^{10}$ For countries with discrepancies among data sources, we opt for the adoption status suggested by the majority (two) of these sources or, when only two sources are available, we determine the status using the source that provides more supporting information for its assessment. When the available information is not sufficient to determine the extent of IFRS adoption or the relevant dates, we supplement it with information from the official websites of national standard setters, securities exchanges, associations of accountants, and web searches of newswire archives. Our searches are limited to websites available in English. Finally, we obtain some additional information from correspondence with the investor relations departments of national securities exchanges and country managing partners at Big-4 audit firms.

\footnotetext{
${ }^{10}$ While the IASB itself relies on IASplus.com as a data source (IASB, 2008a, b), there are a few cases in which other sources disagree with the website's assessment of the country's adoption status. For example, Egypt and Peru are listed on IASplus.com as requiring IFRS for all listed companies, but the PriceWaterhouseCoopers website, the ROSC reports, and at least one (non Deloitte) Big-4 audit partner in each country disagreed with IASplus.com. In these circumstances, we err in favor of the other data sources.
} 
A qualitative analysis of the extent of each country's IFRS adoption leads us to conclude that this process cannot be described with a simple binary variable. Consequently, we classify countries into five different groups based on their degree of IFRS harmonization as described below. First, following the adoption classification on the IASplus.com website, we create four groups: full adopters (when IFRS as issued by the IASB is required for all listed companies); IFRS required for some listed companies; IFRS permitted for (at least some) listed companies; and non-adopters (when IFRS is not permitted for any listed companies). We then refine this classification to include an additional category for countries with an IFRS "convergence" project as discussed in Appendix A.

For the purposes of our primary empirical analysis, we reclassify the five categories of IFRS harmonization described above into three ordinal levels: (1) non-adopters; (2) countries with convergence projects, countries allowing voluntary IFRS adoption, and countries requiring IFRS for some listed companies; and (3) full IFRS adopters. The ordinal levels represent distance from full adoption of IFRS as issued by the IASB. We agglomerate the middle three categories into a single level ("partial adopters") because it is difficult to objectively rank these categories relative to each other. Our primary dependent variable, the three-level ordinal estimated for every country-year in the dataset, is denoted, Adoption $_{i, t}$.

We are able to obtain information about the adoption status for 92 jurisdictions and 552 country-years. The jurisdictions are listed in Appendix B. The 27 countries that compose the member states of the EU, as well as Norway and Iceland which are subject to the European IAS regulation as members of the European Economic Area (EEA), are treated as one observation. ${ }^{11}$ The reason for this treatment is that in 2002 the EU \& the EEA made a joint decision to adopt

\footnotetext{
${ }^{11}$ EU countries are coded as being full adopters between 2005 and 2008, and as having convergence projects with IFRS in 2003 and 2004. Our coding is based on the extent of IFRS harmonization for the majority of EU members.
} 
IFRS by 2005 (EC, 2008) i.e., adoption of IFRS by EU and EEA member states was not made on a country-by-country basis.

Since we are interested in the determination of financial reporting requirements for listed companies, we exclude from our database all jurisdictions that do not have stock exchanges. We also exclude those jurisdictions for which the World Bank's World Development Indicators (WDI) database does not report gross domestic product (GDP) data. Additionally, we exclude jurisdictions without dyadic trade data as reported by the International Monetary Fund (IMF). These data are required to calculate our measure of network benefits (in the following subsection). The process results in 89 jurisdictions and 514 country-years. In tests of alternative explanations, we require the availability of additional data, which reduces the sample size further as seen in Sections IV and V.

Measuring perceived network benefits

The network benefits from IFRS harmonization for a given country $i$ in year $t$ are the economic benefits perceived from commercial relations with the existing base of countries already harmonized with IFRS. We determine "the existing base of countries already harmonized with IFRS" using the country-year data on IFRS adoption described in the previous sub-section. Only full IFRS adopters are included among the countries already harmonized with IFRS when we construct our primary measures of network benefits. This is because partial adoptions result in standards that are used only by a subset of firms in the jurisdiction or are substantially different from IFRS. Due to the limited comparability of these standards, countries may not perceive network benefits from partial adopters. Measuring "the economic benefits perceived from commercial relations" with IFRS adopters is more challenging. 
Conceptually, network benefits are likely to arise from lower perceived transaction costs of foreign investment and trade. Intuitively, foreign direct and portfolio investors incur lower costs analyzing financial statements based on a familiar set of standards. Similarly, accounting standards also play an important role in foreign trade. Cross-border customer and supplier contracts are usually written on accounting numbers since this helps the contracting parties manage supply-chain risk and monitor counterparties when the terms of trade involve financing. This connection between accounting numbers and international trade creates incentives for crossborder trading partners to harmonize accounting standards: the harmonization can lower transaction costs, including costs of information and monitoring. ${ }^{12}$

Because bilateral foreign investment data are needed to construct an empirical measure of investment flows with the subset of countries that have adopted IFRS and the availability of such data is very limited, we are unable to conduct empirical tests using foreign investment. Consequently, we focus on measuring network effects based on anticipated trade benefits; greater data availability on trade allows us to consider a much broader set of countries. Clearly, a trade-based measure captures only a subset of expected networks benefits, but is relevant and informative given the substantial evidence on the role of accounting in contracting.

One relatively simple proxy for the perceived benefits is the aggregate value of existing trade with the subset of IFRS adopting countries relative to the size of the country's economy (GDP). Countries are likely to perceive lower transaction costs from adopting a common set of standards as more crucial when trade with IFRS adopters is more important in their economy.

\footnotetext{
${ }^{12}$ Moreover, there can be trade-related regulatory and litigation reasons for international traders to harmonize with IFRS. For example, Ramanna (2013) identifies "anti-dumping" lawsuits over exports by Chinese manufacturers as a major reason for China's decision to converge with IFRS. These lawsuits usually allege that Chinese manufacturers are selling (or "dumping") goods at prices below cost in overseas markets. By adopting IFRS, Chinese manufacturers can expect to provide more reliable data on their costs, thus justifying in foreign litigation their low prices on exports.
} 
The numerator of this proxy (the aggregate value of trade with IFRS adopters) can be constructed from dyadic (bilateral) trade data obtained from the IMF's Direction of Trade Statistics (DOTS) database. Under this approach,

$$
\operatorname{Network}_{i, t}=\frac{\sum_{j \in J} \operatorname{Trade}_{i j, t-1}}{G D P_{i, t-1}}
$$

Where Trade $_{i j, t-1}$ is the dyadic trade volume between country $i$ and country $j$ in year $t-1$, $i \notin J, J$ is the subset of all jurisdictions that have mandated IFRS for all listed firms (i.e., full adoption), as of year $t-1$, and $G D P_{i, t-1}$ is country i's $G D P$ in year $t-1$.

The problem with this approach is that existing trade data incorporate the effects of country i's imminent IFRS harmonization as well. That is, since we measure harmonization effective of the implementation date, rather than the announcement date, existing trade data are likely to reflect at least some of the realized consequences of country i's impending implementation. For our purposes, we ideally want to separate these realized effects from any measure of economic benefits perceived prior to the harmonization decision. The realized effects can result in either a boost or a decline in existing trade from its latent level (i.e., its level absent impending implementation), depending on the country's institutional features that facilitate contracting efficiency, including auditing, securities laws, courts, and financial intermediaries. For example, if IFRS harmonization decreases contracting efficiency, imports will decrease because customers in country $i$ will suffer worse credit terms (anticipating deteriorating reporting) and exports will decrease because of less reliable measures of financial strength among country i's suppliers. This situation will result in a decrease in overall trade. ${ }^{13}$

\footnotetext{
${ }^{13}$ Confounding the realized and perceived benefits from IFRS harmonization is especially troublesome if the realized effects are negative (i.e., decrease trade) because a country is unlikely to adopt IFRS unless it expects a net benefit from the adoption. In other words, measuring network benefits using existing trade data is particularly
} 
Alternatively, if IFRS harmonization increases contracting efficiency, countries can similarly experience an increase in overall trade..$^{14}$

To obtain a less biased measure of trade, we follow two approaches. In the first approach, we estimate dyadic trade for year $t$ from its three-year lagged value (using an out-of-sample regression to generate the estimate). In the second approach, we use the raw value of dyadic trade from year $t-3$. In both cases, we use three-year lagged trade data because year $t-3$ is the year preceding the likely year in which a country's adoption decision was announced (as noted earlier, we find that adoption decisions lag adoption implementations by two years on average).

More specifically, the first approach proceeds as follows.

(i) We estimate the following out-of-sample regression for years $t$ from 1999 through 2001 (accordingly, years $t-3$ from 1996 through 1998), where Trade $_{i j, t}$ is the dyadic trade volume between country $i$ and country $j$ in year $t$ (scaled by the average of country $i$ 's and country $j$ 's GDP in year $t$ ) and $j \neq i$ :

$$
\text { Trade }_{i j, t}=\alpha_{1} * \text { Trade }_{i j, t-3}+\alpha_{i} *\{\text { Countryif.e. }\}+\alpha_{j} *\{\text { Country } j \text { f.e. }\}+\varepsilon_{i j, t} \ldots(2 a)
$$

(ii) The coefficients from this out-of-sample regression are used to obtain the predicted value of dyadic trade for years $t$ from 2003 through 2008 (accordingly, years $t-3$ from 2000 through 2005) as follows.

$$
\widehat{\operatorname{Trad}_{i, j, t}}=\widehat{\alpha}_{1} * \text { Trade }_{i j, t-3}+\hat{\alpha}_{i} *\{\text { Country i f.e. }\}+\hat{\alpha}_{j} *\{\text { Country j f.e. }\} \ldots(2 b)
$$

(iii) We estimate the network benefits for a given country $i$ in years $t$ from 2003 through 2008 as the aggregated value of $\widehat{\operatorname{Trad}}_{i j, t}$ across the subset of countries already fully adopting

problematic for countries with weak monitoring and information processing institutions, where harmonization is likely to decrease contracting efficiency.

${ }^{14}$ DeFond et al. (2011) provide relevant evidence, albeit in the context of investment flows. In studying U.S. mutual fund ownership among 14 IFRS adopting countries, the authors find either increases or decreases in fund ownership depending on the "credibility" of IFRS implementation across those countries. 
IFRS, where $J$ represents the subset of all jurisdictions $(i \notin J)$ that have mandated IFRS for all listed firms (i.e., full adoption) as of year $t-1$ :

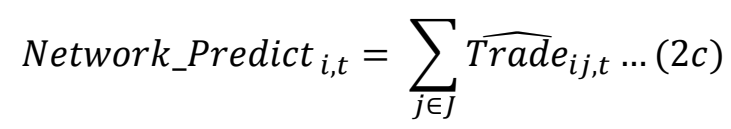

In the above procedure, we use the out-of-sample period prior to year 2002 in step (i) (rather than the in-sample period 2003-2008) because the in-sample period contains trade data subsequent to a country's adoption of IFRS adoption and thus can introduce hindsight bias. The predictive value of network effects from the procedure above has the advantage of using historical data and, at the same time, incorporating anticipated changes in trade which are likely relevant to decision makers: $\widehat{\text { Trad }}_{i j, t}$ accounts for secular increases in trade from year $t-3$, controlling for country-specific effects. Note that the predictive value of the expectation model described above is high, with $\mathrm{R}^{2}$ of $93.81 \%$.

In our second approach, we construct a proxy for network effects from the raw dyadic trade between countries in year $t-3$. For years $t$ from 2003 through 2008 and where $J$ is the subset of all jurisdictions $(i \notin J)$ that have mandated IFRS for all listed firms (i.e., full adoption) as of year $t-1$ :

$$
\text { Network_Raw }{ }_{i, t}=\frac{\sum_{j \in J} \operatorname{Trade}_{i j, t-3}}{G D P_{i, t-3}} \ldots
$$

The correlation between Network_Predict and Network_Raw is 0.69.

\section{Research design}

Our primary tests are ordinary least squares (OLS) regressions of the three-level ordinal ranking of IFRS harmonization on network benefits. The regressions are estimated in the panel of all countries $i$ and years $t$ from 2003 through 2008. Standard errors are clustered by country. We predict $\alpha_{1}$ in the equation below to be positive and statistically significant. 


$$
\text { Adoption }_{i, t}=\alpha_{0}+\alpha_{1} * \text { Network } 1_{i, t}+\alpha_{i} *\{\text { Country } i \text { f.e. }\}+\varepsilon_{i, t} \ldots
$$

We expect a country's economic size to qualify the relation between IFRS harmonization and network benefits (i.e., $\alpha_{1}$ in equation (4)). We measure economic size using the quartile rank of a country's GDP (in constant year 2000 U.S. dollars) and denote it $q(G D P)$. The formal statement of the OLS regression with the size cross-sectional effect estimated over all countries $i$ and years $t$ from 2003 through 2008 is as follows:

$$
\begin{gathered}
\text { Adoption }_{i, t}=\alpha_{0}+\alpha_{1} * \text { Network }_{i, t}+\alpha_{2} * \text { Network }_{i, t} * q(G D P)_{i, t-3}+\alpha_{3} * q(G D P)_{i, t-3} \\
+\alpha_{i} *\{\text { Country } i \text { f.e. }\}+\varepsilon_{i, t} \ldots(5)
\end{gathered}
$$

We predict $\alpha_{1}$ to be positive and statistically significant, and $\alpha_{2}$ to be negative and statistically significant. The use of country fixed effects in equations (4) and (5) is intended to control for cross-sectional variation in institutions that influence a country's choice of accounting standards.

\section{Alternative explanations}

While a number of factors likely contribute to IFRS adoption by countries, our focus in this study is network effects. Thus, in this subsection, we focus on explanations that potentially confound our inferences on network effects (explanations likely captured by variables associated with our measure of network effects).

First, we establish whether our results on network effects are robust to the inclusion of time-based controls since there are numerous possible time-based explanations for the increasing IFRS adoption by countries over our sample period. ${ }^{15}$ We note that, even after including such

\footnotetext{
${ }^{15}$ In the initial set of tests, we exclude year fixed effects because the regressions are intended to test whether our measure of network benefits explains part of the intertemporal variation in IFRS adoption. More specifically, since network benefits are in part determined by which countries have adopted IFRS in the past, and are thus correlated with the average level of adoption over time, the inclusion of time-based controls can extract that part of the variation in IFRS adoption that is attributable to network effects. However, it is important to establish whether network effects are robust to alternative time-based explanations and that is the purpose of including time fixed effects in additional tests.
} 
time-based controls, the network effect can still be identified by our network variable because, both conceptually and empirically, network effects are cross-sectional and time-series in nature.

In the context of testing the network effects hypothesis with country and year fixed effects, the remaining alternative explanations we examine are those that, like network effects, are at least partially panel-based. We identify six such explanations.

The first focuses on the role of the World Bank in encouraging its client countries to embrace IFRS. The World Bank, through its periodic ROSC reports, evaluates the status of a country's corporate governance institutions (including accounting institutions), and then makes recommendations on how that country can progress towards more internationally consistent governance practices (including through IFRS harmonization). The incidence of an ROSC report may thus result in both IFRS adoption and changes in trade, which will be captured by our network effects variable. If so, an association between IFRS adoption and the network effects variable can be due to World Bank pressure rather than network effects. To control for this possibility, we include in robustness tests an indicator variable $W B_{-}$Report $_{i, t}$ to denote whether a World Bank ROSC report was issued for a given country " $i$ " prior to the year " $t$ " in question (i.e., in year $t-1$ or before).

The second alternative explanation we test is based on the idea that IFRS adoption can be part of a country's broader economic globalization, beyond increasing economic relations with IFRS adopters. That is, as a country's economy becomes increasingly reliant on trade over our sample period, the country may initiate associated policy responses such as IFRS adoption, even if such trade were with countries not adopting IFRS. To address this possibility, we include as a control variable the ex-ante share of international trade with non-IFRS adopters in a country's 
GDP: Trade ${ }_{\text {Non-IFRS. }}$ Note that if the increasing reliance on trade in the economy comes from trade with IFRS-adopters, it constitutes a network effect and is captured by Network.

The third alternative explanation is also related to globalization: individual countries' policy responses to globalization (including IFRS harmonization) may vary in time due to differential exposure to international information resources. Implicitly, the greater the exposure to international information, the more likely constituents in a country become interested in globalization. Moreover, differential exposure to international information may affect trade, thus confounding the interpretation of our network effects measure. To mitigate this possibility, we include a variable that proxies for countries' access over time to international information resources: the prevalence of Internet usage in a country-year (Info_Globalization). The data are from the WDI database.

The fourth alternative explanation we test is based on the hypothesis that a country's IFRS adoption and concurrent changes in trade are related to the decision of the Big 4 auditors to enter that jurisdiction. The entrance of the Big 4 into a country can be associated with IFRS adoption either because the firms lobby for such an outcome, or because the implementation costs of IFRS for that country decrease with the presence of auditors experienced in IFRS. We address this hypothesis by including in our regressions an indicator variable, BigAuditor, equal to one for country-years in which all three of the following Big 4 audit firms have offices located in the country: Ernst \& Young, KPMG, and PWC. The data are collected from the firms' websites and through private correspondence with the firms. We have been unable to collect similar information from Deloitte. ${ }^{16}$

\footnotetext{
${ }^{16}$ Our results are robust to an alternative measure of BigAuditor: the proportion of the three audit firms (Ernst \& Young, KPMG, and PWC) with offices located in a given country in a given year.
} 
Fifth, to the extent that over the period 2002-2008 there have been changes in domestic institutions and/or enforcement that were systematically related to trade with IFRS adopters, it is important to control for these changes. This is a challenging task given that the variables used to proxy for domestic institutions and enforcement in prior literature are frequently static and therefore captured in our study by country-fixed effects (for example, common- versus code-law country classification, etc.). Following Kaufmann, Kraay, and Mastruzzi (2007) and Daske et al. (2008), we use Rule of Law which unlike various similar variables, is measured annually. We obtain this variable from the Worldwide Governance Indicators provided by the World Bank. Rule of Law reflects the rules of society, and in particular the quality of contract enforcement, property rights, the police, and the courts, as well as the likelihood of crime and violence.

Finally, we examine whether countries' IFRS adoption decisions can be explained by changes in national governments. That is, the adoption of IFRS and corresponding changes in our network effects variable can simply reflect the policy of a new government to be more global. To address this explanation, we rerun our regressions with government fixed effects in lieu of country fixed effects. Each new government in our panel dataset, as denoted by a new "head of government" in the CIA World Factbook, is identified by a unique fixed effect (the CIA identifies "heads of governments" as presidents in executive republics, prime ministers in Westminster-style governments, and sovereigns in absolute monarchies).

Because our dependent variable is based on the IFRS implementation date (rather than the decision date), and given the average two-year lag between decision and implementation, we lag all control variables by three years. That is, for the dependent variable Adoption $_{i, t}$, where year $t$ ranges from 2003 through 2008, all independent variables are measured as of year $t-3$. This 
is similar to the process described in the previous subsection for our primary independent variables - the network effects measures.

Researchers in international finance and corporate governance often examine countrylevel decisions (see for example, La Porta, Lopez-de-Silanes, and Shleifer, 2008, for a recent review). It is customary in this research to assume that country-level decisions reflect a country's domestic political economy. ${ }^{17}$ In using country-level decisions as the unit of empirical analysis, researchers assume that the domestic political economies that generated such decisions are not correlated with their independent variables of interest. The equivalent assumption in our study would be that variation in countries' perceived networks benefits is not systematically related to variation in their domestic political economies. Instead of relying solely on this assumption, however, we include the control variables described above. That is, while we are unable to analyze and code every feature of domestic political economies in a sample that spans 89 jurisdictions, the three levels of controls described above - country fixed effects, government fixed effects, and Rule of Law - are likely to capture much of the relevant variation.

\section{Results}

\section{Descriptive statistics}

Table 1 presents the distribution of IFRS harmonization categories across the 552 observations for which we were able to determine the IFRS adoption status in the country-year panel. The rows in the table correspond to the three different adoption statuses described in Section III: (1) non-adopters, (2) countries with convergence projects, countries allowing voluntary IFRS use, countries requiring IFRS for some listed companies, and (3) full adopters.

\footnotetext{
${ }^{17}$ More specifically, such decisions are the result of actions by special-interest lobbyists (in our setting: firms, auditors, academics etc.) and ideology-driven regulators (see Kothari, Ramanna, and Skinner, 2010, for an analysis of political-economic theories as they apply to accounting standard setting).
} 
Countries across the three sub-categories in (2) are presented separately. The columns represent the six years in the panel, 2003-2008.

INSERT TABLE 1 HERE.

The proportion of non-adopters, 61 jurisdictions, is highest in 2003; the proportion decreases to 30 jurisdictions by 2008. In contrast, the number of full adopters, i.e., jurisdictions requiring IFRS (as issued by the IASB) for all listed firms, grows from 18 jurisdictions in 2003 to 32 jurisdictions in 2008 . The EU, having adopted IFRS fully in 2005 , is represented as a single observation in this category effective 2005. The number of jurisdictions with IFRS convergence projects is also increasing through the time-series, from six in 2003 to 15 in 2008 . The proportion of jurisdictions permitting voluntary IFRS use and the proportion of jurisdictions requiring IFRS for some listed companies are non-monotonic in the time-series. For example, there are five jurisdictions permitting voluntary IFRS use in 2003, 10 in 2006 and 2007, and eight in 2008. These proportions are likely to vary over time because jurisdictions may choose to "ease in" to IFRS harmonization by first allowing voluntary IFRS use and/or requiring IFRS for some listed companies, before moving to full-scale IFRS adoption.

INSERT TABLE 2 HERE.

Table 2 provides mean and median values for our measures of perceived network effects by adoption year and by the three levels of IFRS harmonization. The sample is the 514 observations for which we are able to obtain data to compute the network effects measures. Network_Predict and Network_Raw have increased substantially between 2003 and 2008 across all categories of IFRS harmonization, although the increase is not always consistent or monotonic. To interpret the average values in Table 2, consider for example, the mean Network_Predict for non-adopters in 2003: 0.01. This value implies that, among non-adopters in 
2003, trade (as estimated by the procedure described in Section III) with countries that fully adopted IFRS as of 2002 accounted on average for 1\% of the non-adopting countries' GDP.

INSERT TABLE 3 HERE.

In Table 3, the mean and median values of our control variables are reported by the three levels of IFRS harmonization and years. The values corresponding to a given year are three-year lagged values, as discussed earlier, to account for the time lapse between the IFRS adoption decision and implementation. GDP in Table 3 is a continuous variable used to generate the insample quartile rank variable, $q(G D P)$, which is the basis for the cross-sectional tests of network effects on country size. The average values of GDP appear to vary across time within the IFRS harmonization categories. This phenomenon is driven more by countries' movements across harmonization categories (due to changes in their harmonization responses) than by changes in the values of GDP for a given country over time. Table 3 also shows the mean and median

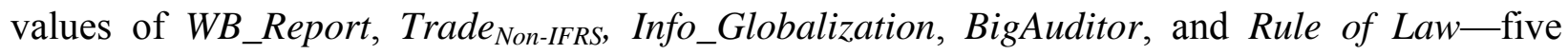
independent variables used in subsequent tests of the alternative explanations to network effects. By construction, the average values of WB_Report increase over time; but there is no discernible difference between its average values across the three IFRS harmonization categories. There is no consistent trend in Trade Non-IFRS $_{-}$- the variable used to test the alternative hypothesis that IFRS adoption can be attributed to globalization of a country's economy that is unrelated to IFRS. Info_Globalization, which is based on Internet usage, is increasing over time. The median value of BigAuditor is one across all categories in Table 3, which is expected given the international presence of the Big 4. Rule of Law fluctuates significantly from year to year within each adoption category, which is largely driven by changes in the composition of these categories. 


\section{OLS regression results}

Table 4 presents the results of OLS regressions of the ordinal IFRS harmonization status on network benefits. The OLS regressions include country fixed effects, and statistical inferences are based on country-clustered standard errors. There are four columns to Table 4 . The first two columns are the result of the regression specified in equation (4) in Section III, i.e., without controlling for country size and its interactive effects with the network variable. In these columns, we report results based on the two alternative network proxies: Network_Predict and Network_Raw. Columns (3) and (4) present the results of regressions specified by equation (5), i.e., with interactive effects. Again, each of these columns uses a different variant of Network as the main independent variable.

\section{INSERT TABLE 4 HERE.}

In columns (1) and (2) of Table 4, the coefficient on the network benefits proxy is positive and statistically significant. The interpretation is that the degree of IFRS harmonization is increasing in perceived network benefits, after controlling for country fixed effects. In columns (3) and (4) of Table 4, the coefficients on the non-interacted network benefits proxies are positive and statistically significant. Further, consistent with our cross-sectional prediction, we find a negative and statistically significant coefficient on network benefits interacted with $q(G D P)$ in column (3). The relevant t-statistic in column (4) is -1.6 , rendering the interaction term insignificant using a two-sided t-test. Overall, there is some evidence consistent with country size attenuating the impact of network benefits on IFRS harmonization.

To evaluate the economic significance of network benefits for countries' IFRS harmonization choices, we calculate the change in IFRS adoption status due to shifting the value of Network_Predict from the $25^{\text {th }}$ to $75^{\text {th }}$ percentile (not tabulated). For a country with average size, the shift in Network_Predict from the $25^{\text {th }}$ to $75^{\text {th }}$ percentile leads to a 0.25 increase in IFRS 
adoption status (i.e., $25 \%$ of the shift from no IFRS-related activities to some harmonization efforts or from some harmonization efforts to full IFRS adoption). However, our cross-sectional results show that this effect is stronger (weaker) for countries that are smaller (larger): for a country in the lowest (highest) size quartile, a shift of two quartiles in the value of Network_Predict leads to a 46\% (5\%) increase in IFRS adoption status. We repeat this analysis for the results based on Network_Raw. Shifting the value of Network_Raw from 0.25 to 0.75 percentile results in a $15 \%$ increase in IFRS adoption status for a country with average size, a $20 \%$ increase for countries in the lowest size quartile, and a $9 \%$ increase for countries in the highest size quartile.

\section{Tests of alternative explanations}

Table 5 presents the results of tests that include year fixed effects and controls for each of the six alternative explanations discussed in Section III. There are two columns to Table 5. The first uses Network_Predict as the main independent variable; the second uses Network_Raw.

INSERT TABLE 5 HERE.

The coefficient on the main effect of Network is positive and statistically significant in both columns of Table 5, suggesting that the main effect of perceived network benefits is robust to year fixed effects and the various alternative explanations discussed in Section III. Also, the interaction of network benefits with $q(G D P)$ yields a negative and statistically significant coefficient in both columns of Table 5 , consistent with country size attenuating the impact of network benefits on IFRS harmonization. Trade ${ }_{\text {Non-IFRS }}$ is negative and statistically significant in column (1) of Table 5. None of the other proxies for the alternative explanations are significant (although in untabulated analyses we find that Info_Globalization and Big Auditor are significant when tested individually). The inclusion of year fixed effects and government fixed effects does not affect inferences on network effects either. Overall, the evidence in Table 5 is consistent with 
network effects being significant determinants of the intertemporal shift from domestic accounting standards to IFRS after controlling for various plausible alternative explanations. As expected, the economic significance of network effects decreases somewhat when we control for these alternative explanations. From the coefficients in column (1), we can say that for a country with average size, the shift in Network_Predict from the $25^{\text {th }}$ to $75^{\text {th }}$ percentile leads to a $15 \%$ increase in IFRS adoption status; for a country in the lowest (highest) size quartile, a shift of two quartiles in the value of Network_Predict leads to a $36 \%$ increase ( $7 \%$ decrease) in IFRS adoption status. From the coefficients in column (2), we can say that for a country with average size, the shift in Network_Raw from the $25^{\text {th }}$ to $75^{\text {th }}$ percentile leads to a $7 \%$ increase in IFRS adoption status; for a country in the lowest (highest) size quartile, a shift of two quartiles in the value of Network_Raw leads to a 17\% increase (3\% decrease) in IFRS adoption status.

\section{Robustness tests and additional analyses}

Our method of coding harmonization levels for the OLS regressions requires that we determine the relative gaps between the levels a priori rather than a posteriori, as would be possible using other models. We use OLS in the main tests because country fixed effects are not feasible in models estimated via MLE: the numerical optimization methods used to recover parameter estimates in MLE do not converge given so many explanatory variables in a relatively small sample. However, we test the robustness of our ordinal harmonization levels by estimating both hazard and multinomial logit regressions. We also re-estimate our OLS regressions using an ordinal with five (rather than three) levels of IFRS adoption as the dependent variable. The description of results from these robustness tests follows. This section also describes additional analyses in which we examine the robustness of our results to alternative definitions of network effects. 


\section{Robustness tests: Hazard model results}

In the hazard regressions, full adoption of IFRS is modeled as the "failure" event, i.e., the dependent variable is the time to full IFRS adoption. The hazard regressions estimate the impact of network benefits on full adoption, accounting for the relative timing of that adoption. Let " $T$ " be the "survival" time, i.e., the number of years until full IFRS adoption. Then, $T=1$ if a country adopts IFRS in 2003, $T=2$ if for adoption in 2004, and so on. Since the data are censored in 2008, the highest possible value for $T$ is six. For countries that do not adopt by 2008 or that harmonize only partially with IFRS, $T$ is set to six and the dependent variable is treated as censored. In additional hazard tests, we relax the latter assumption and treat any harmonization effort at convergence or above (e.g., voluntary adoption) as a "failure" event. We estimate the counting process hazard model (Therneau and Grambsch, 2000). ${ }^{18}$ A positive coefficient on a covariate in the hazard model implies that the likelihood of IFRS full adoption is increasing in the covariate. The primary independent variables in the hazard analyses are variously Network_Predict and Network_Raw and their interactions with the economic size proxy. Since parameter estimates are obtained from MLE, these specifications do not include country fixed effects. Standard errors are clustered at the country level using the process described in Lin and Wei (1989).

Table 6 presents the results from the hazard model. In columns (1) and (2) we measure network benefits with Network_Predict and Network_Raw, respectively, and define the "failure" event as full adoption of IFRS, i.e., the dependent variable is the time to full IFRS adoption. In columns (3) through (4) we recode the dependent variable to represent the time to IFRS harmonization at any level at or above a convergence project.

\footnotetext{
${ }^{18}$ The counting-process method is based on a discrete formulation of the dependent variable (i.e., survival time T), which is likely to be more appropriate for our data than the more familiar Cox model since we measure $T$ in years (the Cox model assumes $T$ is continuous). Moreover, in situations where the range of possible values for $T$ is low (as in the case of our data where $T$ varies between 1 and 6), Box-Steffensmeier and Jones (2004) argue the countingprocess method is likely to be more appropriate for hazard analyses.
} 
INSERT TABLE 6 HERE.

Table 6 provides some evidence that the likelihood of IFRS harmonization (at full adoption or at or above a convergence project) increases in perceived network benefits: coefficients on the main variable of interest (Network) is significant and positive in columns (1) and (3), i.e., when using Network_Predict. Also, consistent with our prediction, the effect of network benefits on the likelihood of IFRS harmonization is weaker for larger countries, as demonstrated by the statistically significant negative coefficient on Network* $q(G D P)$ in column (1); but this interaction is not significant in column (3). In contrast to the results from Table 5, the coefficients on Network_Raw and Network_Raw* $q(G D P)$ are not statistically significant in Table 6. This difference in results can be attributed either to estimating different types of model (OLS versus hazard) or to the lack of sufficient controls - the hazard model does not include country or government fixed effects. The economic significance of network effects in countries' decisions to adopt IFRS is weaker when these decisions involve any type of adoption (columns (3) and (4)), rather than exclusively full IFRS adoption (columns (1) and (2)).

\section{Robustness tests: Multinomial logit model results}

We re-estimate the full specification with alternative explanations as a multinomial logit model (not tabulated). The dependent variable in our multinomial logit model is IFRS harmonization. Harmonization is coded as one of three categories: non-adoption, partial adoption, and full adoption. The multinomial logit model does not assume any ordering among the harmonization levels. Instead, it compares the partial adoption and full adoption categories to the base-line decision, non-adoption.

Overall results from the multinomial logit model yield similar conclusions to the ones from the hazard model: there is some evidence that perceived network benefits increase the probability a country fully adopts IFRS. More specifically, when we analyze decisions to fully 
adopt IFRS, we find that the coefficient on Network_Predict - but not Network_Raw - is positive and statistically significant. We find no support for our cross-sectional prediction on size in this test. Finally, there is no significant association between network effects and a country's decision to partially adopt IFRS.

Robustness tests: OLS regressions with five levels of IFRS adoption status

In untabulated tests, we examine the robustness of our OLS regression results to using an ordinal with five (rather than three) levels of IFRS adoption as the dependent variable. The five levels are discussed in Section III. These robustness tests confirm our inferences from Tables 4 and 5: perceived network benefits defined as Network_Predict or Network_Raw are positively and significantly associated with IFRS adoption status and more important for smaller countries. Inferences from the robustness tests are unaffected by the inclusion of year fixed effects and controls for alternative explanations.

Additional analyses: alternative definitions of economic networks

In calculating our primary proxies (Network_Predict and Network_Raw), trade with countries pursuing convergence, countries permitting voluntary adoption, and countries requiring only partial adoption are not included. As noted earlier, "convergence" is a loosely defined term that can result in different sets of standards in different countries. Further, voluntary and partial adoption efforts are not equivalent to full adoption because they require different levels of adaptation to IFRS among complementary institutions such as auditing. Consequently, countries may not expect IFRS adoption to result in strong trade benefits when accounting standards of their trade partners are based on modified or partial IFRS adoption. To examine whether that is indeed the case, we repeat our tests using two alternative measures of network benefits: Network_Predict_Conv and Network_Raw_Conv. These variables are similar to 
Network_Predict and Network_Raw, except that, for a given country $i$, they are calculated by aggregating dyadic trade with all other jurisdictions that have: (i) converged with IFRS; (ii) made IFRS available for voluntary use; (iii) mandated IFRS for at least some listed firms; or (iv) mandated IFRS for all listed firms (i.e., full adoption), as of year $t-1$.

INSERT TABLE 7 HERE.

The results are reported in Table 7, columns (1) and (2) and are similar to those in Table 5. In particular, we observe a positive and statistically significant coefficient on the main network effect and a negative significant coefficient on its interaction term with size. The coefficients are somewhat smaller than in Table 5, indicating the including less than full adoptions weakens the economic magnitude of network effects. Nevertheless, these findings imply that countries do perceive some network benefits even from partial IFRS adoption among trading partners.

Additionally, we define another set of measures of network benefits to test whether economic relations with non-EU countries can explain the impact of network benefits on IFRS adoption. The EU had a dominant role in the establishment of the IASB and EU countries continue to exercise discretion over the Board (e.g., Ramanna, 2013). Moreover, EU countries adopted IFRS jointly, potentially providing the critical mass of commitment to IFRS needed to generate network benefits. Given the EU's central status vis-à-vis IFRS, it is possible that benefits perceived from relations with the EU are overriding in explaining network effects. The variables — Network_Predict_Non-EU and Network_Raw_Non-EU — are similar to Network_Predict and Network_Raw, except that, for a given country $i$, they are calculated by aggregating dyadic trade with full adopters (as of year $t-1$ ) that are non-EU/ non-EEA memberstates. 
Table 7, models (3) and (4), report the results of this additional analysis. We find mixed results. When using Network_Predict_Non-EU, the main effect and the interaction with size yield coefficients consistent with findings in Table 5 (albeit statistically significant at the $90 \%$ confidence level). When using Network_Raw_Non-EU, neither coefficient is statistically significant, consistent with network effects being largely driven by perceived trade benefits with the EU/EEA adopters of IFRS. This result evokes caution in our overall interpretation of IFRS being self-reinforcing since the EU/EEA adoption is a significant source of network benefits.

Additional analyses: colonial ties and geographic proximity as alternative sources of network effects

As discussed earlier, network effects may also arise from geographic proximity and relations with former colonizers. Specifically, decision makers in a country may become more familiar with IFRS and more likely to adopt it as the country's neighbors adopt IFRS. Further, as a country's former colonizer adopts IFRS, longstanding shared practices might drive it to adopt IFRS. These geographic and colonizer effects likely represent forms of network effects but can exist independently of economic networks captured by our primary measures. Thus, we define two additional variables (\% Neighbors_Adopted and Colonizer_Adopted) and include them as control variables in robustness tests. \% Neighbors_Adopted in year $t$ is defined as the percentage of a country's geographically contiguous neighbors that have adopted IFRS as of year $t-3$. Colonizer_Adopted is an indicator set to one for every year $t$ in which a country's former colonizer made the decision to adopt IFRS as of year $t-3$ or earlier.

INSERT TABLE 8 HERE.

Table 8 presents the results of tests that include $\%$ Neighbors_Adopted and Colonizer_Adopted. The two columns in Table 8 use, respectively, Network_Predict and Network_Raw as the main independent variable. The results in Table 8 are similar to those in 
Table 5. In particular, we observe a positive and statistically significant coefficient on the main network effect and a negative significant coefficient on its interaction term with size, consistent with economic network effects driving IFRS adoption. Neither \% Neighbors_Adopted nor Colonizer_Adopted is statistically significant in the regressions, suggesting that the IFRS adoption status of neighbors and former colonizers is not a significant predictor of a country's adoption status. ${ }^{19}$

\section{Conclusion}

We develop and test the hypothesis that network effects are a significant factor in the time-series growth in IFRS harmonization across countries. Network effects refer to perceived lower transactions costs given the community of IFRS adopters worldwide. We find the degree of IFRS harmonization in a country is an increasing function of the perceived value of its IFRS network. The results suggest IFRS adoption is self-reinforcing, although our evidence also suggests that a significant proportion of perceived network benefits accrue from IFRS adoption by just EU and EEA member-states. In cross-sectional tests, we explore how a country's economic size is likely to affect the relation between network benefits and IFRS harmonization. We find evidence consistent with network effects mattering more to countries with smaller GDPs. Our evidence implies that countries with low bargaining power are more susceptible to adopting IFRS because others are doing so, consistent with such countries being less distinctive in their approach to IFRS harmonization. Ironically, low bargaining power countries (i.e., countries with lower GDP) also tend to have weak market institutions, implying IFRS implementation in these countries is less likely to be effective.

\footnotetext{
${ }^{19}$ The results in Table 8 are substantively invariant to using an alternative for \% Neighbors_Adopted - specifically, a measure of geographic proximity based on the average distance between a country $i$ and countries $j$ that have adopted IFRS.
} 
The presence of network effects in the adoption of IFRS is significant because it means a country can adopt IFRS even if its domestically developed accounting standards are particularly well-suited to its domestic institutions. Moreover, if network effects contribute to the adoption of IFRS, they can sustain its eventual dominance even in the presence of technologically superior innovations (David, 1985). ${ }^{20}$ The evidence in this paper can also complement the growing literature on the determinants and consequences of firms' IFRS adoption. Firms' adoption decisions are conditional on countries' decisions to harmonize with IFRS, suggesting that the analysis of why countries adopt IFRS is important. The growing literature on the consequences of IFRS adoption to firms can, in turn, inform studies that analyze country-level decisions; governments are likely to consider expected firm-level consequences when choosing to allow or require IFRS.

The concept of network effects has recently been used to explain several accountingrelated phenomena, such as the adoption of stock-option compensation plans (Kedia and Rajgopal, 2009) and the decision to expense options in the income statement (Reppenhagen 2010). We document that network effects influence accounting-related decisions more generally, suggesting network theory can be used broadly in the literature on accounting and corporate governance choice. For example, the theory of IFRS network benefits tested herein in the context of countries can equivalently be applied to firms. Future firm-level research can investigate whether network benefits increase the attractiveness of voluntary IFRS adoptions to multinational as opposed to domestic corporations.

\footnotetext{
${ }^{20}$ For example, David notes how the QWERTY keyboard has remained the world standard despite longstanding experimental evidence (dating back to at least the 1940s) supporting alternative keyboard designs as superior.
} 


\section{References}

Armstrong, C., M.E. Barth, A.D. Jagolinzer, and E.J. Riedl. 2010. Market reaction to the adoption of IFRS in Europe. The Accounting Review 85: 31-61.

Ball, R. 2006. International Financial Reporting Standards (IFRS): pros and cons for investors. Accounting \& Business Research 36: 5-27.

- S.P. Kothari, and A. Robin. 2000. The effect of international institutional factors on properties of accounting earnings. Journal of Accounting \& Economics 29: 1-51.

A. Robin, and J. Wu. 2003. Incentives versus standards: Properties of accounting income in four East Asian countries. Journal of Accounting \& Economics 36: 235-270.

Benston, G.J., M. Bromwich, R.E. Litan, and A. Wagenhofer. 2006. Worldwide financial reporting: The development and future of accounting standards. New York: Oxford University Press.

Box-Steffensmeier, J.M., and B.S. Jones. 2004. Event history modeling: A guide for social scientists. New York: Cambridge University Press.

Bradshaw, M. and G. Miller. 2008. Will harmonizing accounting standards really harmonize accounting? Evidence from non-U.S. firms adopting U.S. GAAP. Journal of Accounting, Auditing and Finance 23: 233-263.

Bushman, R. and J. Piotroski. 2006. Financial reporting incentives for conservative accounting: The influence of legal and political institutions. Journal of Accounting \& Economics 42: $107-148$.

Daske, H., L. Hail, C. Leuz, and R. Verdi. 2008. Mandatory IFRS reporting around the world: early evidence on the economic consequences. Journal of Accounting Research 46: 10851142.

David, P. 1985. Clio and the Economics of QWERTY. American Economic Review 75: 332-337.

DeFond, M., X. Hu, M. Hung, and S. Li. 2011. The impact of mandatory IFRS adoption on foreign mutual fund ownership: The role of comparability. Journal of Accounting \& Economics 51: 240-258.

EC (Commission of the European Communities). 2008. Table of decisions of Member States and EEA Countries concerning the use of options in the IAS Regulation. Brussels, Belgium: EC. http://ec.europa.eu/internal_market/accounting/docs/ias/ias-use-of-options_en.pdf.

Hail, L., C. Leuz, and P. Wysocki. 2010. Global accounting convergence and the potential adoption of IFRS by the U.S. (Part I): Conceptual underpinnings and economics analysis. Accounting Horizons 24: 355-394. 
Himalayan News Service. 2012. Country to adopt IFRS. November 28. Available at: http://www.thehimalayantimes.com/fullNews.php?headline=Country+to+adopt+IFRS $+\& N$ ewsID $=355888$.

Hope, O., J. Jin, and T. Kang. 2006. Empirical evidence on jurisdictions that adopt IFRS. Journal of International Accounting Research 5: 1-20.

International Accounting Standards Board (IASB). 2008a. The IASC Foundation's Annual Report 2007. London, UK: IASB. http://www.iasb.org/NR/rdonlyres/99A983BD-191F474B-87A9-E25BB9D7093C/0/IASCF_annual_report_2007.pdf.

- 2008b. IASB and the IASC Foundation: Who we are and what we do. London, UK: IASB. $\quad \mathrm{http}: / / w w w . i a s b . o r g / N R /$ rdonlyres/0A5A767C-E7DE-49E5-8B12499F62F8870C/0/WhoWeAre_Final12508.pdf.

- 2009. IASC Foundation Annual Report. London, UK: IASB. http://www.iasb.org/NR/rdonlyres/473C971C-2C13-444F-A94F706C996F645C/0/Annualreport20092.pdf.

Kaufmann, Kraay, and Mastruzzi. 2007. Governance matters VI: Aggregate and individual governance indicators. Working Paper, The World Bank.

Katz, M.L., and C. Shapiro. 1985. Network externalities, competition, and compatibility. American Economic Review 75: 424-440.

Kedia, S., and S. Rajgopal. 2009. Neighborhood matters: The impact of location on broad based stock option plans. Journal of Financial Economics 92: 109-127.

Kothari, S., Ramanna, K., Skinner, D., 2010. Implications for GAAP from an analysis of positive research in accounting. Journal of Accounting \& Economics 50: 246-286.

La Porta, R., F. Lopez-de-Silanes, and A. Shleifer. 2008. The economic consequences of legal origins. Journal of Economic Literature 46: 285-332.

Lang, M., M. Maffett, and E. Owens. 2010. Earnings comovement and accounting comparability: The effects of mandatory IFRS adoption. Working Paper \#11-03, Simon School of Business.

Leuz, C. 2010. Different approaches to corporate reporting regulation: how jurisdictions differ and why. Accounting and Business Research 40 (3): 1-28.

Liebowitz, S.J., and S.E. Margolis. 1994. Network externality: An uncommon tragedy. Journal of Economic Perspectives 8: 133-150.

and 1 1998. Network externalities (effects). In The New Palgrave's dictionary of economics and the law, ed. Peter Newman. London: Palgrave MacMillan. 
Lin, D.Y., and L.J. Wei. 1989. The robust inference for the Cox proportional hazards model. Journal of the American Statistical Association 84: 1074-1078.

Márquez-Ramos, L. 2008. The effect of IFRS adoption on trade and foreign direct investments. Working Paper \#19, International Trade and Finance Association.

Modern Ghana. 2006. Ghana adopts international financial reporting standards next year. December 15. Available at: http://www.modernghana.com/news/120436/1/ghana-adoptsinternational-financial-reporting-sta.html.

Patel, P. 2007. Update from Standards Committee. FIA Journal, 1. Available at: http://www.iasplus.com/en/binary/asia/0708fiji.pdf.

Ramanna, K. 2013. The international politics of IFRS harmonization. Accounting, Economics, and Law 3: 1-46.

- G.A. Donovan, and N. Dai. 2010. IFRS in China. Harvard Business School Case 110037.

Reppenhagen, D.A. 2010. Contagion of accounting methods: evidence from stock option expensing. Review of Accounting Studies 15: 629-657.

Sarkissian, S., and M.J. Schill. 2004. The overseas listing decision: New evidence of proximity preference. Review of Financial Studies 17(3): 769-809.

Skinner, D. 2008. The rise of deferred tax assets in Japan: The role of deferred tax accounting in the Japanese banking crisis. Journal of Accounting \& Economics 46: 218-239.

Therneau, T.M., and P. M. Grambsch. 2000. Modeling survival data: Extending the Cox model. New York: Springer-Verlag.

USAID Armenia. 2010. International Financial Reporting Standards for Small and Medium Entities Now Available in Armenian. June 2. Available at: http://armenia.usaid.gov/en/news-events/281.

Währisch, M. 2001. The evolution of international accounting systems. Frankfurt am Main: Lang.

World Bank. 1999-2008. Reports on Observance of Standards and Codes. http://www.worldbank.org/ifa/rosc.html. 


\section{Appendix A, Defining the category for countries with an IFRS “convergence” project}

Through a qualitative analysis of IFRS adoption patterns across countries, we encounter jurisdictions that have made some progress towards IFRS harmonization, but whose domestic standards continue to differ from IFRS as issued by the IASB. In particular:

1. Some countries develop national accounting standards that are based on, but not identical to, IFRS. For example, the Institute of Chartered Accountants of Nepal lists the various Nepalese Accounting Standards (NAS) together with their corresponding IFRS equivalents. NAS are produced in English and appear to be derived from IFRS; however, not every IFRS has an equivalent NAS and extant NAS differ in wording from IFRS.

2. Other countries claim to have adopted IFRS but carve out certain standards or rules, often supplementing IFRS with local exceptions. For example, Ramanna et al. (2010) describe various exceptions to IFRS that China has carved out as a condition to converging with the global standards, including standards around consolidated financial reporting, fair-value accounting, and reversal of impairments.

3. Still other countries rely on "static" IFRS - that is, they use a version of IFRS that was effective as of some prior year. For example, PriceWaterhouseCoopers reports that current IFRS is neither required nor permitted for listed companies in Thailand, but that "Thai GAAP follows the 2005 version of IFRS," with certain exceptions.

The countries described above cannot be properly classified as having adopted IFRS as issued by the IASB. Accordingly, we reclassify the countries as IFRS "convergence" countries, where "convergence" represents a country's efforts to reconcile its domestic accounting standards with IFRS, in lieu of directly adopting IFRS as issued by the IASB. Creating the "convergence" category results in differences between our score of IFRS adoption and that on Deloitte's IASplus.com: for example, Nepal is classified as a "full adopter" on IASplus.com. 


\section{Appendix B, List of jurisdictions in the dataset (IFRS adoption codes for the 2003-2008 period in parentheses)}

See Appendix $\mathrm{C}$ for a description of the IFRS adoption codes. No data in parenthesis indicates that the country had no significant IFRS harmonization activity through 2008 .

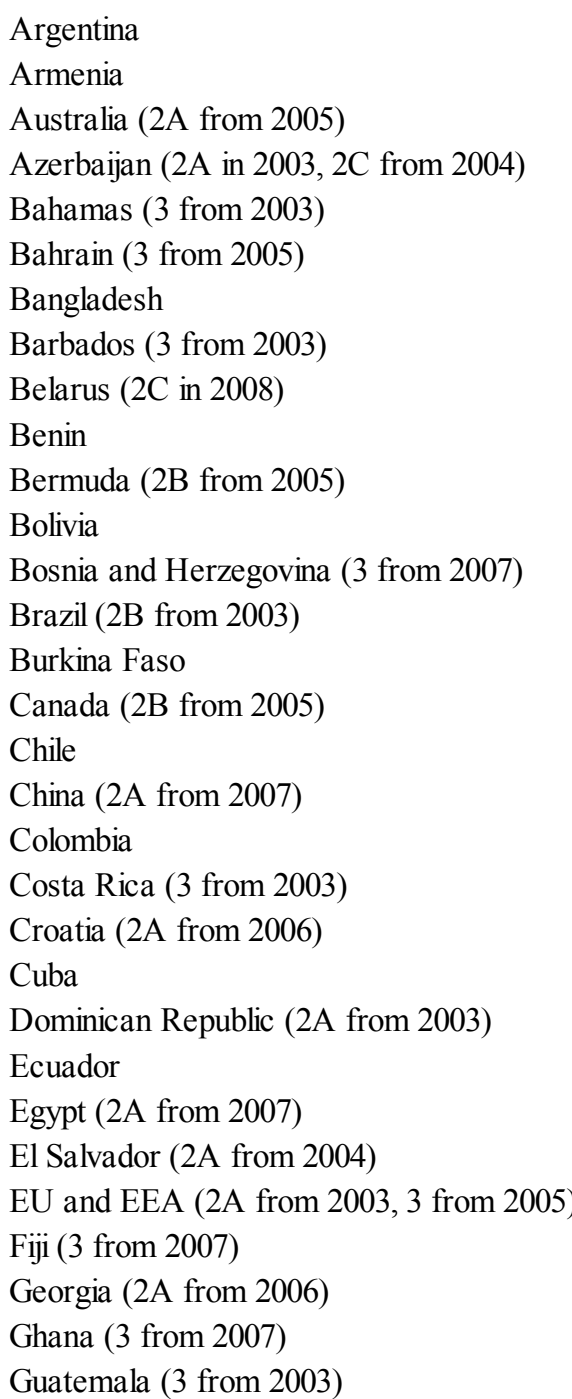

Guyana (3 from 2003)
Haiti
Honduras (3 in 2008)
Hong Kong (2A from 2003, 2B from 2003)
India
Indonesia
Iran
Israel (2B from 2006, 3 in 2008)
Ivory Coast
Jamaica (3 from 2003)
Japan
Jordan (3 from 2003)
Kazakhstan (2C from 2003, 3 from 2005)
Kenya (3 from 2003)
Korea (South)
Kuwait (3 from 2003)
Kyrgyzstan
Laos
Lebanon (3 from 2003)
Macedonia (2A from 2004)
Malawi (3 from 2003)
Malaysia
Mali
Mauritius (3 from 2003)
Mexico
Moldova (3 in 2008)
Morocco (2C in 2008)
Mozambique (2C in 2008)
Nepal
New Zealand (2A from 2005)
Nicaragua (2B from 2004)

\author{
Niger \\ Oman (3 from 2003) \\ Pakistan (2A from 2006) \\ Panama (2C from 2003) \\ Papua New Guinea (3 from 2003) \\ Paraguay (2B from 2003) \\ Peru (2A from 2003) \\ Philippines (2A from 2003) \\ Qatar (3 from 2003) \\ Russia (2C from 2004) \\ Saudi Arabia (2C from 2007) \\ Singapore \\ South Africa (2B from 2003, 3 from 2005) \\ Sri Lanka (2B from 2004) \\ Switzerland (2B from 2003) \\ Syria \\ Tajikistan (3 from 2007) \\ Tanzania (3 from 2004) \\ Thailand (2A from 2007) \\ Togo \\ Trinidad and Tobago (3 from 2003) \\ Tunisia \\ Turkey (2B from 2003) \\ Ukraine \\ United Arab Emirates (3 from 2003) \\ United States \\ Uruguay (2A from 2004) \\ Venezuela \\ Zambia (3 from 2005) \\ Zimbabwe (3 from 2003)
}




\section{Appendix C, Variable definitions}

\begin{tabular}{|c|c|c|}
\hline \multicolumn{2}{|l|}{ Variable } & Description \\
\hline \multicolumn{3}{|c|}{ Dependent variable: IFRS (IFRS adoption status) } \\
\hline 1. Non adopter & & Countries with no IFRS harmonization activity \\
\hline \multirow[t]{3}{*}{ 2. Partial adoption } & A. Convergence project & $\begin{array}{l}\text { Countries attempting to reconcile their domestic accounting standards } \\
\text { with IFRS, without directly adopting IFRS }\end{array}$ \\
\hline & B. Voluntary adoption & $\begin{array}{l}\text { Countries permitting at least some listed firms in their jurisdiction to } \\
\text { adopt IFRS as issued by the IASB }\end{array}$ \\
\hline & C. Required for some & $\begin{array}{l}\text { Countries requiring IFRS as is sued by the IASB for some listed firms } \\
\text { in their jurisdiction }\end{array}$ \\
\hline 3. Full adoption & & $\begin{array}{l}\text { Countries requiring IFRS as is sued by the IASB for all listed firms in } \\
\text { their jurisdiction }\end{array}$ \\
\hline
\end{tabular}

Primary independent variable: Network value of IFRS

Network_Predict

Network_Raw

Newtork_Predict_Conv, Newtork_Raw_Conv

Newtork_Predict_NonEU, Newtork_Raw_NonEU

\section{Other independent variables}

$q(G D P)$

WB_Report

Trade $_{\text {Non-IFRS }}$

Info_Globalizaion

BigAuditor

Rule of Law

Colonizer_Adopted

$\%$ Neighbors_Adopted
Predicted ratio of a country's trade with all countries that have IFRS adoption status "3" relative to their GDP, where trade and GDP as of year $t-3$ predict the ratio in the adoption year $t$

Ratio of a country's trade with all countries that have IFRS adoption status " 3 " relative to the country's GDP, where trade and GDP are measured as of year $t-3$

Defined similar to Newtork_Predict and Network_Raw, except based on a country's trade with all countries that have IFRS adoption status "2A," "2B", "2C" or "3"

Defined similar to Newtork_Predict and Network_Raw, except based on a country's trade with all non-EU/ non-EEA countries that have IFRS adoption status "3"

In-sample quartile rank of gross domestic product as of year t-3

Time-series indicator to denote whether a World Bank ROSC report was issued for the given country in year $\mathrm{t}-3$ or before

The ratio of a country's foreign trade with juris dictions not adopting IFRS to the country's GDP, where trade and GDP are measured in year t-3

Percentage of Internet users as of year t-3

Indicator equal to one if Ernst \& Young, KPMG, and PWC have offices located in the country as of year t-3

Score of -2.5 to 2.5 from Kaufmann, Kraay, and Mastruzzi (2007) where higher values represent stronger quality of enforcement, measured as of year t-3

Indicator set to one for every year $t$ in which a country's former colonizer made the decision to adopt IFRS as of year t-3 or earlier $\%$ of a country's neighbors that adopted IFRS, measured as of year t-3 


\section{Table 1, IFRS adoption status in the country-year panel}

"Non adopter" refers to countries with no IFRS harmonization activity. "Partial adoption" refers to applying IFRS with exception or only for some firms in the economy and includes: "Convergence project," "Voluntary adoption," and "Required for some." "Convergence project" refers to countries attempting to reconcile their domestic accounting standards with IFRS, without directly adopting IFRS. "Voluntary adoption" refers to countries permitting at least some listed firms in their jurisdiction to adopt IFRS as issued by the IASB. "Required for some" refers to countries requiring IFRS as issued by the IASB for some listed firms in their jurisdiction. "Full adoption" refers to countries requiring IFRS as issued by the IASB for all listed firms in their jurisdiction.

\begin{tabular}{|c|c|c|c|c|c|c|c|}
\hline Adoption Status & 2003 & 2004 & 2005 & 2006 & 2007 & 2008 & Total \\
\hline 1. Non adopter & 61 & 54 & 48 & 44 & 36 & 30 & 273 \\
\hline \multicolumn{8}{|l|}{ 2. Partial adoption } \\
\hline A. Convergence project & 6 & 8 & 8 & 11 & 14 & 15 & 62 \\
\hline B. Voluntary adoption & 5 & 7 & 9 & 10 & 10 & 8 & 49 \\
\hline C. Required for some & 2 & 4 & 3 & 3 & 4 & 7 & 23 \\
\hline \multirow[t]{2}{*}{ 3. Full adoption } & 18 & 19 & 24 & 24 & 28 & 32 & 145 \\
\hline & 92 & 92 & 92 & 92 & 92 & 92 & 552 \\
\hline
\end{tabular}




\section{Table 2, Descriptive statistics for measures of perceived network benefits}

"Non adopter" refers to countries with no IFRS harmonization activity. "Partial adoption" refers to applying IFRS with exception or only for some firms in the economy and includes: "Convergence project," "Voluntary adoption," and "Required for some." "Convergence project" refers to countries attempting to reconcile their domestic accounting standards with IFRS, without directly adopting IFRS. "Voluntary adoption" refers to countries permitting at least some listed firms in their jurisdiction to adopt IFRS as issued by the IASB. "Required for some" refers to countries requiring IFRS as issued by the IASB for some listed firms in their jurisdiction. "Full adoption" refers to countries requiring IFRS as issued by the IASB for all listed firms in their jurisdiction. Network_Predict is the predicted ratio of a country's trade with all countries that have IFRS adoption status " 3 " relative to their GDP, where trade and GDP are measured as of year t-3. Network_Raw is the ratio of a country's trade with all countries that have IFRS adoption status "3" relative to the country's GDP, where trade and GDP are measured as of year t-3. Med. denotes median.

\begin{tabular}{|c|c|c|c|c|c|c|c|c|c|c|c|c|c|}
\hline \multirow[b]{2}{*}{ Adoption Status } & \multirow[b]{2}{*}{ Variable } & \multicolumn{2}{|c|}{2003} & \multicolumn{2}{|c|}{2004} & \multicolumn{2}{|c|}{2005} & \multicolumn{2}{|c|}{2006} & \multicolumn{2}{|c|}{2007} & \multicolumn{2}{|c|}{2008} \\
\hline & & Mean & Med. & Mean & Med. & Mean & Med. & Mean & Med. & Mean & Med. & Mean & Med. \\
\hline \multirow[t]{2}{*}{ 1. Non adopter } & Network_Predict & 0.010 & 0.004 & 0.013 & 0.005 & 0.013 & 0.004 & 0.056 & 0.037 & 0.062 & 0.038 & 0.073 & 0.044 \\
\hline & Network_Raw & 0.011 & 0.003 & 0.016 & 0.006 & 0.017 & 0.007 & 0.264 & 0.196 & 0.263 & 0.186 & 0.263 & 0.172 \\
\hline \multirow[t]{2}{*}{ 2. Partial adoption } & Network_Predict & 0.007 & 0.004 & 0.015 & 0.012 & 0.014 & 0.013 & 0.080 & 0.046 & 0.099 & 0.065 & 0.109 & 0.070 \\
\hline & Network_Raw & 0.006 & 0.004 & 0.021 & 0.010 & 0.022 & 0.011 & 0.257 & 0.163 & 0.260 & 0.179 & 0.314 & 0.182 \\
\hline \multirow[t]{2}{*}{ 3. Full adoption } & Network_Predict & 0.025 & 0.012 & 0.032 & 0.021 & 0.033 & 0.026 & 0.075 & 0.055 & 0.072 & 0.054 & 0.089 & 0.073 \\
\hline & Network_Raw & 0.042 & 0.020 & 0.053 & 0.043 & 0.052 & 0.037 & 0.293 & 0.258 & 0.338 & 0.282 & 0.431 & 0.322 \\
\hline
\end{tabular}




\section{Table 3, Descriptive statistics for other independent variables}

"Non adopter" refers to countries with no IFRS harmonization activity. "Partial adoption" refers to applying IFRS with exception or only for some firms in the economy and includes: "Convergence project," "Voluntary adoption," and "Required for some." "Convergence project" refers to countries attempting to reconcile their domestic accounting standards with IFRS, without directly adopting IFRS. "Voluntary adoption" refers to countries permitting at least some listed firms in their jurisdiction to adopt IFRS as issued by the IASB. "Required for some" refers to countries requiring IFRS as issued by the IASB for some listed firms in their jurisdiction. "Full adoption" refers to countries requiring IFRS as issued by the IASB for all listed firms in their jurisdiction. GDP is gross domestic product as of year t-3. WB_Report is a time-series indicator to denote whether a World Bank ROSC report was issued for the given country in year t-3 or before. Trade $_{\text {Non-IFRS }}$ is the ratio of a country's foreign trade with jurisdictions not adopting IFRS to the country's GDP, where trade and GDP are measured in year t-3. Info Globalization is the percentage of Internet users as of year t-3. BigAuditor is an indicator equal to one for country-years in which Ernst \& Young, KPMG, and PWC have offices located in the country as of year t-3. Rule of Law varies between -2.5 and 2.5 and higher values capture stronger quality of enforcement, measured as of year t-3 (Kaufmann, Kraay, and Mastruzzi, 2007). Med. denotes median.

\begin{tabular}{|c|c|c|c|c|c|c|c|c|c|c|c|c|c|}
\hline \multicolumn{2}{|c|}{ Data for Adoption Year } & \multicolumn{2}{|c|}{2003} & \multicolumn{2}{|c|}{2004} & \multicolumn{2}{|c|}{2005} & \multicolumn{2}{|c|}{2006} & \multicolumn{2}{|c|}{2007} & \multicolumn{2}{|c|}{2008} \\
\hline Adoption Status & Variable & Mean & Med. & Mean & Med. & Mean & Med. & Mean & Med. & Mean & Med. & Mean & Med. \\
\hline \multirow[t]{6}{*}{ 1. Non adopter } & $G D P$ & 353.9 & 19.2 & 402.7 & 20.9 & 432.0 & 21.5 & 488.1 & 22.7 & 554.4 & 23.8 & 688.7 & 48.6 \\
\hline & WB_Report & 0.000 & 0.000 & 0.000 & 0.000 & 0.043 & 0.000 & 0.093 & 0.000 & 0.257 & 0.000 & 0.276 & 0.000 \\
\hline & Trade $_{\text {Non-IFRS }}$ & 0.533 & 0.476 & 0.557 & 0.472 & 0.644 & 0.501 & 0.527 & 0.425 & 0.607 & 0.419 & 0.695 & 0.466 \\
\hline & Info_Globalization & 8.836 & 2.019 & 11.918 & 3.359 & 10.712 & 4.038 & 13.138 & 5.401 & 16.039 & 6.376 & 18.194 & 7.400 \\
\hline & BigAuditor & 0.644 & 1.000 & 0.635 & 1.000 & 0.617 & 1.000 & 0.605 & 1.000 & 0.571 & 1.000 & 0.552 & 1.000 \\
\hline & Rule of Law & -0.212 & -0.448 & -0.214 & -0.413 & -0.369 & -0.560 & -0.349 & -0.507 & -0.391 & -0.680 & -0.343 & -0.569 \\
\hline \multirow[t]{6}{*}{ 2. Partial adoption } & $G D P$ & 799.8 & 77.2 & 573.4 & 22.8 & 165.8 & 58.3 & 154.1 & 61.2 & 225.5 & 94.4 & 213.1 & 50.8 \\
\hline & WB_Report & 0.000 & 0.000 & 0.000 & 0.000 & 0.000 & 0.000 & 0.043 & 0.000 & 0.148 & 0.000 & 0.276 & 0.000 \\
\hline & Trade $_{\text {Non-IFRS }}$ & 0.630 & 0.587 & 0.582 & 0.546 & 0.666 & 0.561 & 0.509 & 0.431 & 0.560 & 0.447 & 0.594 & 0.470 \\
\hline & Info_Globalization & 12.250 & 5.189 & 12.865 & 6.824 & 22.902 & 11.419 & 23.079 & 13.057 & 22.400 & 13.933 & 23.752 & 17.350 \\
\hline & BigAuditor & 0.846 & 1.000 & 0.789 & 1.000 & 0.842 & 1.000 & 0.870 & 1.000 & 0.926 & 1.000 & 0.897 & 1.000 \\
\hline & Rule of Law & -0.123 & -0.325 & -0.157 & -0.458 & 0.121 & -0.497 & 0.102 & -0.224 & 0.069 & -0.144 & -0.088 & -0.441 \\
\hline \multirow[t]{6}{*}{ 3. Full adoption } & $G D P$ & 14.9 & 8.5 & 16.43 & 9.88 & 452.2 & 10.9 & 464.4 & 11.7 & 488.6 & 10.1 & 50.4 & 10.8 \\
\hline & WB_Report & 0.000 & 0.000 & 0.063 & 0.000 & 0.048 & 0.000 & 0.238 & 0.000 & 0.400 & 0.000 & 0.417 & 0.000 \\
\hline & Trade $_{\text {Non-IFRS }}$ & 0.600 & 0.567 & 0.574 & 0.528 & 0.623 & 0.596 & 0.477 & 0.506 & 0.542 & 0.486 & 0.664 & 0.575 \\
\hline & Info_Globalization & 6.638 & 5.894 & 9.551 & 8.567 & 12.563 & 8.599 & 13.952 & 11.900 & 12.884 & 8.161 & 15.600 & 13.184 \\
\hline & BigAuditor & 0.882 & 1.000 & 0.875 & 1.000 & 0.905 & 1.000 & 0.905 & 1.000 & 0.800 & 1.000 & 0.833 & 1.000 \\
\hline & Rule of Law & 0.078 & 0.375 & -0.154 & -0.334 & -0.138 & -0.276 & -0.103 & -0.193 & -0.264 & -0.325 & -0.276 & -0.479 \\
\hline
\end{tabular}




\section{Table 4, OLS regressions of IFRS adoption status}

The dependent variable is IFRS adoption status (Adoption) which takes the value of 1 for non-adopters, 2 for partial adoption, and 3 for full adoption Network_Predict is the predicted ratio of a country's trade with all countries that have IFRS adoption status " 3 " relative to their GDP, where trade and GDP as of year t-3. Network_Raw is the ratio of a country's trade with all countries that have IFRS adoption status "3" relative to the country's GDP, where trade and GDP are measured as of year t-3. $q(G D P)$ is the in-sample quartile rank of gross domestic product as of year t-3. Standard errors are clustered by country. Numbers in italics are t-statistics.

\begin{tabular}{rcccc}
\hline \multicolumn{5}{c}{ Dependent Variable=Adoption } \\
\hline (1) & $\mathbf{( 2 )}$ & $\mathbf{( 3 )}$ & $\mathbf{( 4 )}$ \\
\hline \multirow{2}{*}{ Network $=$} & Network_Predict & Network_Raw & Network_Predict & Network_Raw \\
\hline Network & $2.153^{* * *}$ & $0.823 * * *$ & $11.895^{* * *}$ & $1.176^{* * *}$ \\
& $(3.85)$ & $(5.52)$ & $(4.43)$ & $(3.66)$ \\
q(GDP) & & & 0.181 & 0.141 \\
& & & $(1.00)$ & $(0.72)$ \\
Network*q(GDP) & & & $-2.744 * * *$ & -0.183 \\
& & & $(-3.96)$ & $(-1.60)$ \\
Constant & $1.617 * * *$ & $1.589 * * *$ & $1.116 * * *$ & $1.268 * * *$ \\
& $(62.79)$ & $(69.09)$ & $(2.69)$ & $(2.82)$ \\
Country F.E. & & & & \\
N Obs. & Yes & Yes & Yes & Yes \\
Adj R Square & 514 & 514 & 514 & 514 \\
& 0.087 & 0.156 & 0.164 & 0.164 \\
\hline
\end{tabular}

$* * *, * *$ and $*$ denote statistical significance at the two-tail $99 \%, 95 \%$, and $90 \%$ confidence levels, respectively. 


\section{Table 5, OLS regression of IFRS adoption status - tests of alternative explanations}

The dependent variable is IFRS adoption status (Adoption) which takes the value of 1 for non-adopters, 2 for partial adoption, and 3 for full adoption. All proxies for Network as well as other independent variables are defined in Appendix $\mathrm{C}$ and in notes to Tables 2 and 3. Standard errors are clustered by government. Numbers in italics are tstatistics.

\begin{tabular}{|c|c|c|}
\hline \multicolumn{3}{|c|}{ Dependent Variable $=$ Adoption } \\
\hline & (1) & $(2)$ \\
\hline Network $=$ & Network_Predict & Network_Raw \\
\hline \multirow[t]{2}{*}{ Network } & $10.001 * * *$ & $1.144 * * *$ \\
\hline & $(2.90)$ & (3.13) \\
\hline \multirow[t]{2}{*}{$q(G D P)$} & $-0.524 * *$ & $-0.532 *$ \\
\hline & $(-2.03)$ & $(-1.89)$ \\
\hline \multirow[t]{2}{*}{ Network*q(GDP) } & $-2.826 * * *$ & $-0.319 * *$ \\
\hline & $(-3.28)$ & $(-2.24)$ \\
\hline \multirow[t]{2}{*}{ WB_Report } & 0.089 & 0.068 \\
\hline & -0.560 & $(0.45)$ \\
\hline \multirow[t]{2}{*}{ Trade Non-IFRS } & -0.309 & -0.209 \\
\hline & $(-1.68)$ & $(-1.00)$ \\
\hline \multirow[t]{2}{*}{ Info_Globalization } & 0.005 & 0.007 \\
\hline & $(0.47)$ & $(0.66)$ \\
\hline \multirow[t]{2}{*}{ BigAuditor } & -0.165 & -0.123 \\
\hline & $(-1.40)$ & $(-1.05)$ \\
\hline \multirow[t]{2}{*}{ Rule of Law } & $0.399 *$ & 0.360 \\
\hline & $(1.79)$ & $(1.49)$ \\
\hline \multirow[t]{2}{*}{ Constant } & $2.898 * * *$ & $2.848 * * *$ \\
\hline & $(4.35)$ & $(4.09)$ \\
\hline Government F.E. & Yes & Yes \\
\hline Country F.E. & No & No \\
\hline Year F.E. & Yes & Yes \\
\hline N Obs. & 506 & 506 \\
\hline Adj R Square & 0.289 & 0.291 \\
\hline
\end{tabular}

$* * *, * *$, and $*$ denote statistical significance at the two-tail $99 \%, 95 \%$, and $90 \%$ confidence levels, respectively. 


\section{Table 6, Counting-process hazard regression of IFRS adoption status}

In columns (1) and (2) full adoption is defined as the failure event. In columns (3) and (4) convergence and higher levels of adoption are defined as the failure event. All proxies for Network as well as other independent variables are defined in Appendix $\mathrm{C}$ and in notes to Tables 2 and 3. Standard errors are clustered by country. Numbers in italics are $\chi 2$ statistics.

\begin{tabular}{|c|c|c|c|c|}
\hline Failure $=$ IFRS adoption & Full & Full & $\begin{array}{c}\text { Convergence or } \\
\text { Above }\end{array}$ & $\begin{array}{c}\text { Convergence or } \\
\text { Above }\end{array}$ \\
\hline & (1) & $(2)$ & (3) & $(4)$ \\
\hline Network $=$ & Network_Predict & Network_Raw & Network_Predict & Network_Raw \\
\hline \multirow[t]{2}{*}{ Network } & $20.163 * * *$ & 0.290 & $10.274 * *$ & -0.028 \\
\hline & (13.69) & $(0.11)$ & $(5.01)$ & $(0.00)$ \\
\hline \multirow[t]{2}{*}{$q(G D P)$} & $-0.793 * * *$ & $-0.768 * * *$ & $-0.391 * * *$ & $-0.378 * * *$ \\
\hline & $(31.22)$ & (25.78) & $(16.71)$ & $(15.10)$ \\
\hline \multirow[t]{2}{*}{ Network* $q(G D P)$} & $-3.717 * *$ & 0.181 & -1.729 & 0.194 \\
\hline & (5.97) & $(0.21)$ & (1.82) & $(0.47)$ \\
\hline \multirow[t]{2}{*}{ WB_Report } & $0.767 * * *$ & $0.548 *$ & 0.042 & -0.041 \\
\hline & $(7.34)$ & (3.68) & $(0.04)$ & $(0.04)$ \\
\hline \multirow[t]{2}{*}{ Trade Non-IFRS } & -0.289 & -0.180 & $-0.504 * * *$ & $-0.330 * *$ \\
\hline & (1.59) & $(0.57)$ & $(9.64)$ & $(4.68)$ \\
\hline \multirow[t]{2}{*}{ Info_Globalization } & $-0.018 *$ & -0.010 & 0.002 & 0.003 \\
\hline & $(3.31)$ & $(1.08)$ & $(0.08)$ & $(0.26)$ \\
\hline \multirow[t]{2}{*}{ BigAuditor } & $1.170 * * *$ & $1.389 * * *$ & $1.337 * * *$ & $1.426 * * *$ \\
\hline & (14.96) & (21.87) & (37.09) & $(43.72)$ \\
\hline \multirow[t]{2}{*}{ Rule of Law } & $0.573 * * *$ & $0.473 * *$ & $0.232 *$ & 0.213 \\
\hline & $(8.87)$ & $(6.44)$ & $(3.06)$ & $(2.65)$ \\
\hline N Obs & 512 & 512 & 512 & 512 \\
\hline Pseudo R Square & 0.199 & 0.158 & 0.131 & 0.113 \\
\hline
\end{tabular}

$* * *, * *$, and $*$ denote statistical significance at the two-tail $99 \%, 95 \%$, and $90 \%$ confidence levels, respectively 


\section{Table 7, Additional analysis: alternative definitions of network effects}

The dependent variable is IFRS adoption status (Adoption) which takes the value of 1 for non-adopters, 2 for partial adoption, and 3 for full adoption. All proxies for Network as well as other independent variables are defined in Appendix $\mathrm{C}$ and in notes to Table 3. Standard errors are clustered by government. Numbers in italics are t-statistics.

\begin{tabular}{|c|c|c|c|c|}
\hline \multicolumn{5}{|c|}{ Dependent Variable $=$ Adoption } \\
\hline & (1) & $(2)$ & (3) & (4) \\
\hline Network = & $\begin{array}{c}\text { Network_Predict_ } \\
\text { Conv }\end{array}$ & $\begin{array}{c}\text { Network_Raw_ } \\
\text { Conv }\end{array}$ & $\begin{array}{c}\text { Network_Predict_ } \\
\text { Non-EU }\end{array}$ & $\begin{array}{l}\text { Network_Raw_ } \\
\text { Non-EU }\end{array}$ \\
\hline \multirow[t]{2}{*}{ Network } & $8.398 * *$ & $0.578 *$ & $14.402 *$ & 1.215 \\
\hline & $(2.23)$ & $(1.76)$ & $(1.96)$ & $(0.85)$ \\
\hline \multirow[t]{2}{*}{$q(G D P)$} & $-0.399 *$ & -0.454 & $-0.432 * *$ & $-0.583 * *$ \\
\hline & $(-1.68)$ & $(-1.64)$ & $(-2.03)$ & $(-2.32)$ \\
\hline \multirow[t]{2}{*}{ Network*q(GDP) } & $-2.620 * *$ & $-0.234 *$ & $-4.973 *$ & 0.332 \\
\hline & $(-2.51)$ & $(-1.90)$ & $(-1.92)$ & $(0.29)$ \\
\hline \multirow[t]{2}{*}{ WB_Report } & 0.085 & 0.102 & 0.139 & 0.035 \\
\hline & $(0.53)$ & $(0.61)$ & $(0.77)$ & $(0.74)$ \\
\hline \multirow[t]{2}{*}{ Trade Non-IFRS } & -0.203 & -0.110 & -0.071 & -0.086 \\
\hline & $(-0.93)$ & $(-0.38)$ & $(-0.32)$ & $(-0.27)$ \\
\hline \multirow[t]{2}{*}{ Info_Globalization } & 0.006 & 0.008 & 0.008 & 0.008 \\
\hline & $(0.59)$ & $(0.71)$ & $(0.64)$ & $(0.65)$ \\
\hline \multirow[t]{2}{*}{ BigAuditor } & $-0.244 *$ & -0.165 & -0.172 & -0.148 \\
\hline & $(-1.72)$ & $(-1.31)$ & $(-1.39)$ & $(-1.28)$ \\
\hline \multirow[t]{2}{*}{ Rule of Law } & $0.358 *$ & 0.371 & $0.425 *$ & $0.459 *$ \\
\hline & $(1.66)$ & $(1.50)$ & $(1.86)$ & (1.93) \\
\hline \multirow[t]{2}{*}{ Constant } & $2.550 * * *$ & $2.596 * * *$ & $2.537 * * *$ & $2.866 * * *$ \\
\hline & $(4.15)$ & (3.88) & $(4.65)$ & $(4.60)$ \\
\hline Government F.E. & Yes & Yes & Yes & Yes \\
\hline Year F.E. & Yes & Yes & Yes & Yes \\
\hline N Obs. & 506 & 506 & 506 & 506 \\
\hline Adj R Square & 0.280 & 0.255 & 0.253 & 0.254 \\
\hline
\end{tabular}

$* * *, * *$, and $*$ denote statistical significance at the two-tail $99 \%, 95 \%$, and $90 \%$ confidence levels, respectively. 
Table 8, Additional analysis: colonial ties and geographic proximity as alternative sources of network effects

The dependent variable is IFRS adoption status (Adoption) which takes the value of 1 for non-adopters, 2 for partial adoption, and 3 for full adoption. All proxies for Network as well as other independent variables are defined in Appendix $\mathrm{C}$ and in notes to Table 3. Standard errors are clustered by government. Numbers in italics are t-statistics.

\begin{tabular}{|c|c|c|}
\hline \multicolumn{3}{|c|}{ Dependent Variable $=$ Adoption } \\
\hline & (1) & $(2)$ \\
\hline Network $=$ & Network_Predict & Network_Raw \\
\hline \multirow[t]{2}{*}{ Network } & $10.515 * * *$ & $1.137 * * *$ \\
\hline & $(3.02)$ & $(3.08)$ \\
\hline \multirow[t]{2}{*}{$q(G D P)$} & $-0.501 * *$ & $-0.527 * *$ \\
\hline & $(-2.22)$ & $(-2.09)$ \\
\hline \multirow[t]{2}{*}{ Network*q(GDP) } & $-2.870 * * *$ & $-0.275 *$ \\
\hline & $(-3.32)$ & $(-1.77)$ \\
\hline \multirow[t]{2}{*}{ WB_Report } & 0.098 & 0.064 \\
\hline & $(0.62)$ & -0.430 \\
\hline \multirow[t]{2}{*}{ Trade Non-IFRS } & $-0.314 *$ & -0.200 \\
\hline & $(-1.68)$ & $(-0.97)$ \\
\hline \multirow[t]{2}{*}{ Info_Globalization } & 0.003 & 0.005 \\
\hline & $(0.32)$ & $(0.58)$ \\
\hline \multirow[t]{2}{*}{ BigAuditor } & -0.154 & -0.123 \\
\hline & $(-1.25)$ & $(-1.00)$ \\
\hline \multirow[t]{2}{*}{ Rule of Law } & $0.364 *$ & 0.326 \\
\hline & $(1.77)$ & $(1.52)$ \\
\hline \multirow[t]{2}{*}{ Colonizer_Adopted } & -0.013 & 0.066 \\
\hline & $(-0.10)$ & $(0.51)$ \\
\hline \multirow[t]{2}{*}{ \% Neighbors_Adopted } & -0.003 & -0.002 \\
\hline & $(-1.06)$ & $(-0.74)$ \\
\hline \multirow[t]{2}{*}{ Constant } & $2.838 * * *$ & $2.832 * * *$ \\
\hline & $(4.81)$ & $(4.53)$ \\
\hline Government F.E. & Yes & Yes \\
\hline Country F.E. & No & No \\
\hline Year F.E. & Yes & Yes \\
\hline N Obs. & 506 & 506 \\
\hline Adj R Square & 0.292 & 0.293 \\
\hline
\end{tabular}

$* * *, * *$, and $*$ denote statistical significance at the two-tail $99 \%, 95 \%$, and $90 \%$ confidence levels, respectively. 